The International Journal of the History of Sport, 2015

http://dx.doi.org/10.1080/09523367.2015.1037745

\title{
Olympic stadiums and Cultural heritage: on the nature and status of heritage values in large sport facilities.
}

\author{
Miranda Kiuri, Jacques Teller \\ LEMA, ArGEnCo Dept., ULg, Liege, Belgium
}

\section{Introduction}

Since Antiquity the Olympic Games (OG) have influenced sport facility design. The site of Olympia is an example of how sports facilities are directly and tangibly associated with an event which became of universal significance (ICOMOS, 1988). This stadium remains the most emblematic of the many Olympic places, as it was born as result of the event, its objectives and values. It is a space that has become culturally significant (Kiuri, 2009; Kiuri \& Teller, 2012).

Today the Games still play an important role in the evolution of the buildings, sites and landscapes and their uses (Schmidt, 2002; Kiuri \& Reiter, 2013). There are 24 Olympic stadiums in the world where the Summer Olympic Games have been staged: fifteen in Europe, three in Asia, four in North America (including Mexico City, and the Los Angeles stadium that served both the 1932 and 1984 Games), and two in Australia.

By nature all Olympic stadiums are exceptional. Their singularity can be explained by their size and the universal value of the Games as propounded by the International Olympic Committee (IOC). All these stadiums are clearly related to some aspect of our recent global history. Their significance hence goes far beyond their strict architectural value into political, social and sporting dimensions as well. (Kiuri \& Teller, 2012). Modern Olympic Games can generate cultural ideas and highlight cultural identity. They can also help to address local history, as was for instance the case in Australia during the 2000 Sydney Olympic Games. (Gratton and Preuss, 2008)

Accordingly some Olympic stadiums are now listed as cultural heritage items at different levels - local, national or global. The heritage value of some has been a matter of debate, as in the case of Helsinki's Olympic stadium. (Kairamo, 1999) The history of Olympic stadiums is marked by demolitions, important controversial modifications or extensions. Conservation is always a challenge given the changing needs of spectators at modern sporting spectacles; appropriate standards of comfort and security for both athletes and public are constantly evolving. Very often the focus of conservation is placed on buildings, site and landscape characteristics to the detriment of the sporting events for which they were created, though the importance of sports heritage places as repositories of memory is increasingly acknowledged in literature and in practice. (Velluet, 2012) "Conserving the significance of sporting places is not just about preservation. It can also be about encapsulating old memories in new uses." Heritage categories are themselves undergoing a constant evolution to accommodate both tangible and intangible values, local memory, social issues etc. (Vecco, 2010) In parallel with this process, the selection criteria for recognition as cultural heritage have also changed. While initially historic and artistic values were the only parameters considered, other aspects have progressively been added: cultural value, identity value, and the capacity of the object to interact with memory. (Vecco, 2010) 
The aim of this paper is to evidence specific characteristics of Olympic stadiums in terms of heritage. The next section hence addresses the issue of Olympics and sports heritage, both in the literature and in practice. We will first present three significant cases of controversy: the Wembley Olympic stadium built for the Games of London in 1948, the Foro Italico site of the Olympics in Rome 1960 and the case of the landscape complex that hosted the Games of 1936 in Berlin. The information regarding these controversies about listed stadiums is based essentially on official heritage texts prepared by English Heritage -the UK Government's lead body for the historic environment-, the International Council on Monuments and Sites (ICOMOS), the ICOMOS National Committees and the International Committee for Documentation and Conservation of Buildings, sites and neighbourhoods of the Modern Movement (DoCoMoMo) - Italy documentation. Secondary literature sources were also consulted for analysing the complex history of some of the stadium controversies.

In the next section of the paper we present six cases concerning listed Olympic stadiums and two objects that are part of Olympic stadium ensembles. We introduce basic information concerning these stadiums and will then analyse the values that justified the listing of these elements as heritage. Our methodology is based on an analysis of the official decisions regarding the listing of these elements as local, national or world cultural heritage. This helped us to identify "value descriptors" that are then classified into three categories. The results of this value analysis highlight a specific Olympic heritage profile, related to the uniqueness or singularity of the buildings and landscape.Their evolution over time is usually taken into consideration in the value analysis and the relationship of the places with noteworthy socio-political and sporting events.

In the final part of the paper, we discuss the most relevant characteristics of Olympic stadium heritage, trying to highlight how heritage listing could benefit large sports events. This will lead us to raise the relevancy of a specific heritage category dedicated to sport. The reinterpretation of Olympic stadium heritage in association with the OG themselves, considered as intangible cultural heritage, could allow a better Olympic and sporting heritage evaluation to be developed.

\section{Olympic and Sporting Heritage}

Cultural significance is defined by the values of the object, of its environment and of the activity in its social dimension. Values study is an effective guide to characterization of heritage. (Mason, 2002) When it comes to sport heritage, some of the greatest challenges are posed by the biggest and most iconic venues. (Moore-Gwyn, 2012) Olympic stadiums have always been exceptional, non-recurrent architectures and environments related to unique events. (Kiuri and Reiter, 2013) Olympic facilities have been integrated into the urban areas of the host city in different ways. (Liao and Pitts, 2012) A sustainable conservation of Olympic stadiums requires a due consideration of both the heritage values of these buildings and the requirements for their continued interactions with the city environment. (Liao and Pitts, 2012)

Here below we will study the complexity of Olympic heritage through value typologies and through the particularity of this heritage.

\section{Heritage values typologies}

There are different heritage value typologies. (Mason, 2002) The Austrian art historian Alois Riegl addressed heritage values typology and the "conflict" between them in his 
seminal work Der moderne Denkmalkultus. The heritage values proposed by Riegl in 1903 are Age, Historical, Commemorative, Use, Newness. González-Varas (2005) summarized the evolution of heritage values through history, based on Riegl's work, as (i) age (antiquity and abstract beauty), (ii) historical evolution and emotional values, (iii) commemorative values, and (iv) contemporaneous (use) values.

Contemporaneous values raise specific issues for Olympic stadiums. In 1984 William Lipe presented a new typology of values, based on a differentiation between economic, aesthetic, associative-symbolic and informational values. In 1997 Bruno Frey presented his monetary, existence, prestige, educational and bequest typology. English Heritage formalized in 1997 its own typology, based on Cultural, Educational \& Academic, Resource, Recreation and Aesthetic values. The Burra Charter of the Australian ICOMOS in its last edition from 1999 evokes Aesthetic, Historic, Scientific and Social (spiritual/political/national) values.

There are clear overlaps among these typologies, especially in their recognition of bequest and use values. Accordingly Mason in 2002 proposed to regroup heritage values in two main areas, socio-cultural and economic values. Socio-cultural values include historical, cultural (symbolic), social, spiritual and aesthetic values. Economic values cover use, maintenance and functional dimensions. These obviously raise specific questions for Olympic facilities, especially if the possible reuse and transformation of the facilities after the Games has not been taken into consideration at the design stage.

\section{Sporting heritage}

Sporting heritage presents some particularities as its consideration as a building, site or landscape would remain partial because this heritage has specific interdependence with places (cities, environment) and traditions (events).

English heritage experts recommend a specific analysis of sporting heritage, including local customs, celebrations and traditions that people associate with sports venues, recognising the importance that public memory accords to them. "The narrow focus of listing, with its concentration on special architectural and historic interest, does not allow us to recognise the huge value of sporting sites as repositories of shared memories, the emotional connection that spectators and participants have with particular places and traditions." (Abercrombie, 2012) Besides this, the functional design of sporting facilities and the constantly evolving requirements of various sports mean that a form of permanent protection is "inappropriate", according to heritage experts. At the same time there is not enough research into their larger historical and cultural significance. (Pearson, 2012)

\section{Olympic heritage}

The outstanding values of the Olympic Games of Antiquity were recognized when UNESCO added the site of Olympia to the World Cultural Heritage (WCH) in 1989. Olympia is altogether an environmental, socio-cultural and historical landmark. (Unesco, 2012) It is an example of deep interdependence between tangible and intangible heritage values. The built Olympic heritage (tangible) and the intangible values of the modern Games are deeply connected. "In any event, beyond the fact that the modern Olympics are, in a sense, a type of reclaimed and resurrected heritage, the event itself overtly employs heritage symbols, traditions and rituals". (Gammon et. al., 2013) 
The Olympic Games play an important role in the evolution of stadium architecture. (Gammon et. al., 2013) The singularity of modern Olympic stadiums can be explained by their size and the universal value of the modern Games.

The IOC's Olympic Charter codifies the principles of modern Olympism. Olympism, conceived by Pierre de Coubertin, keeps inspiring the Games through its principles and essential values. When the media highlighted the national importance of the London 2012 Games, focusing on infrastructure and the event itself, this overshadowed the cultural aspects of Olympism in some ways. (Stevenson, 2012) This redirection of emphasis could be observed already in 1948 during the Games of the XIV Olympiad hosted in London. (Bolz, 2012)

De Coubertin declared that the Olympic Games are not simply a championship (Delsahut, 2004). The modern Olympic Games pay homage to their origins, whether to the ancient Games of Greece or to the philosophies and ideals laid down by the father of the modern Olympics. (Delsahut, 2004) De Coubertin philosophy combines abstract principles with romantic-emotional dimensions highlighting their historic roots, while directing these values towards the field of instrumental (contemporaneous) values in modern society. (Kiuri, 2009) Such a philosophy appears consistent with Riegl's views of value evolution (Gonzalez-Varas, 2005). Coubertin and Riegl worked during the same historical period, between the late $19^{\text {th }}$ and early $20^{\text {th }}$ centuries, when an understanding of heritage values started influencing the public discourse. (GonzalezVaras, 2005 ; Gold \& Gold, 1910) However, de Coubertin's appeals to such value sets had a more politically pragmatic character (Chatziefstathiou and Henry, 2007). What was important to him was the restoration of the Games "sur des bases conformes aux nécessités du temps". De Coubertin perceived sport to be an instrument for changing pedagogical methods and aspirations (de Coubertin, 1930). It has to be acknowledged though that the instrumental use of sport for different purposes, by different social actors and with different political intentions is a controversial topic. As we know from history, sport can nourish "idéologies de la force" and the quest for "sociétés pures" and be linked to nationalism (Mendiangue, 2004).

\section{Olympic stadium heritage}

Olympic stadiums constitute a unique piece of heritage, both as a kind of singular architecture and as a testimony to the society that produced those specific environments. (Mendiangue, 2004). Olympic stadiums are among the most important sporting venues, a status conferred on them by the Olympic Games, by their celebration, ceremonies and symbols. Their significance is defined by the values of the building, of the environment and of the sport activity itself.

Of the 24 stadiums that have been built since the beginning of the Olympics of the modern era in 1896, five have been totally or partially demolished, while seven have been significantly transformed or enlarged. One of those stadiums is a reconstruction of an ancient stadium - the Athens Panathenaic stadium that hosted the 1898 Olympics. This stadium was listed as National Heritage in 1998, one year after Athens was awarded the right to host the Games of the XXVIII Olympiad in 2004.

The modern stadiums of Amsterdam (1928) and Los Angeles (1932 \& 1984) are listed as national heritage buildings. The 1984 Games is a rare example where authorities decided to refurbish an existing stadium rather than build a new structure. (Rennie Short, 2009) The stadium of the Games celebrated in Melbourne in 1956, the Melbourne Cricket Ground, has been included in the Australian National Heritage List since 2005. The stadium of Mexico City is part of a site that was declared by UNESCO 
in December 2007 to be World Heritage, as ICOMOS considered its conservation to be at risk, mainly related to the development of the surrounding areas (ICOMOS, 2007).

Some objects that are part of the Olympic stadium ensembles can also be listed as heritage. This has occurred with the Moscow Olympic complex 1980 and Sydney 2000 Olympic Park, both of which include objects declared heritage.

Some listed stadium buildings still retain their original character, as for example the stadium in Stockholm (Gold \& Gold, 2011). Others changed or have being transformed. In some cases there has been important discussions regarding their architectural or historical significance. The first transformation of the historical sporting ground created in Berlin in 1909 have been long discussed. In springtime of the 1929 it was unanimously agreed that the stadium of Berlin would have to be enlarged (Kluge, 2009) As a modern construction, the stadium of Helsinki lost a lot of its "original avantgarde elegance" (Kluge, 2009). The Rome 1960 Olympic stadium was transformed in 1990 (for the football World Championship) by the addition of a covering that was not present initially. More and more it can be seen that discussions concentrate on problems of construction and maintenance of Olympic stadium buildings and the costs incurred by them. This was the case with the Montreal Olympic Stadium for the OG in 1976. These discussions have increasingly influenced stadium design.

The city of London staged the Olympics three times (1908, 1948 and 2012), and with a different Olympic stadium each time. Two of those stadiums were demolished. One of them was the Empire Wembley, which was delisted from the National Heritage list in 2003.

Several modern Olympic stadiums were technological catalysts that contributed to the conceptual advancement of outstanding sports facilities. Very often they have been elements in significant urban compositions and influenced their city from an urban planning perspective. The relationship of Olympic stadiums with the hosting city is now claimed to play a role in developing a sustainable society, respectful of its natural and cultural resources as well as its territory (Kluge, 2009).

Still the maintenance of this heritage usually raises serious concerns as these stadiums and places were built for a unique event, and are not necessarily fit for other purposes. It is a clear case where bequest values -those related to uniqueness, memory, history, culture and, in some respects, aesthetics- clearly conflict with use values -those related to the possible reuse of existing structures for similar or new functions. The mismatch between the bequest and use values of Olympic stadiums has led to some serious social and political controversies over time. These will be discussed in the next section.

\section{Three controversies about Olympic stadium conservation}

The delisting and 2003 demolition of the Wembley stadium building of the Games of the XIV Olympiad in London led to a heated controversy about the conservation of heritage values related with Olympic facilities. The Wembley Stadium was already legendary before the Olympics. To host the 1948 event, considerable alterations were thought to be needed in order to offer the best possible facility for athletes and spectators, though the financing of the works was limited by the austerity policies of the immediate postwar period. The new athletics track at Wembley was completed in 1947 (Kluge, 2009). The stadium was also the first in Olympic history to host athletes with disabilities (Kluge, 2009).

The Foro Italico Olympic site in Rome also generated considerable controversy surrounding perceived conflicts between bequest and use values. In 1928 works were 
started in the vicinity of Monte Mario for the hosting of the OG, expected then in 1944. The Stadio dei Marmi was erected in 1932 and the Stadio dei Cipressi in 1936. The construction of the Stadio Olimpico itself was not commenced until the fifties. (Bolz, 2008) The Games of 1960 offered the ideal platform to enhance a new national and democratic identity. At the same time as the Olympic constructions pushed the development of the city toward modernisation, it also aimed to integrate the long history of Roman culture and thereby to neutralize the recent Fascist past. (Spaziosport, 2015) The entire site transmits the message of harmony between built and natural elements. (Spaziosport, 2015) The quality of this significant architectural, urban and environmental historical complex is now at risk because of the recent expansion and transformation of the site.

The Berlin Olympic stadium and its remarkable landscape setting present a third type of controversy. This monumental sports complex once symbolizedthe power of sport in service of national socialist ideology and politics, which later raised debates about the conservation of the site. The former Reichssportfeld is now one of the major complete buildings remaining from the Third Reich period. The stadium has been modernized so as to become the National Arena of Germany. The architectonic and symbolic language of the place are the testimony of a long historical process. The stadium hosts many prestigious sporting and cultural events, which has helped to consolidate its image as a high quality international venue, while serving at the same time as the stadium for the entire city and contributing towards overcoming the dark side of its past. (Kluge, 2009) The symbolic approach to nature that characterizes the composition and the unique landscape setting are arguably a distinctive feature of the site (Kluge, 2009).

Quite interestingly all three stadiums (London, Rome and Berlin) were part of Olympic sport facilities that set new benchmarks in the landscape of European cities during the interwar years (Bolz, 2008). The nature of the controversies related to their transformation/demolition is described below. The discussion is based on publications and reports of concerned Heritage bodies as well as documents issued by ICOMOS.

\section{Wembley: The destruction of the 1948 Olympic stadium}

Wembley Stadium, originally the British Empire Exhibition Stadium, was constructed in 1922-23. It was opened in 1923 for the British Empire Exhibition of 1924. "The stadium was completed in a record time because innovative constructional techniques were employed, in situ reinforced concrete rather than the iron, steel and timber hitherto used for sport stadia". "Designed to accommodate 120,000, it was made memorable by its now legendary twin towers, $126 \mathrm{ft}$ high and clearly taking their cue from Lutyens' work in the imperial capital of New Delhi - the aim was to give to the functional structure a monumental gloss, with the finish of the concrete treated to resemble masonry". (Powel, 2002)

The stadium was the major venue for the Olympic Games in 1948. It hosted numerous other sporting and music events since then. England won the 1966 Football World Cup at Wembley. The stadium occupied a central place in British sport for decades. It was also one of the world's most famous football stadiums with its iconic twin towers. The Wembley Stadium was added to the National List of Special Architectural or Historic Interest in October 1976. Despite this listing the stadium was altered over the years. In 2000 it was finally closed and slated for demolition. The demolition of the two towers in 2002-03 marked the end of a long running debate about the future of these familiar landmarks on the skyline of northwest London. The athletics 
lobby expressed its dissatisfaction with the new project for a football stadium excluding athletics from Wembley. (Powel, 2002) "The decision to demolish the towers aroused some controversy, but it was accepted by bodies such as English Heritage and the Twentieth Century Society on the grounds that, in isolation, they would be meaningless remnants. Even so, doubts about the financial viability of the scheme remained, leading to pressure for increased seating and revenue-earning commercial development around the stadium". (Powel, 2002) In his article "Wembley - Myth or Monument?" Kenneth Powell confirmed that the towers had a symbolic value and presented some doubts regarding the newly designed landmark for Wembley. "The first Foster's structure appeared not sufficiently distinctive and too similar to other big world stadiums shape. The arch redesigned in 1999 had the goal to create a stronger symbolic and functional architectonic element". (Powel, 2002) Some fifteen years later opinions differ as to whether this arch really has become a distinctive symbolic element in London's landscape, as the iconic twin towers were, or whether the structure is merely a repetitive element of other stadiums (Picture 1).

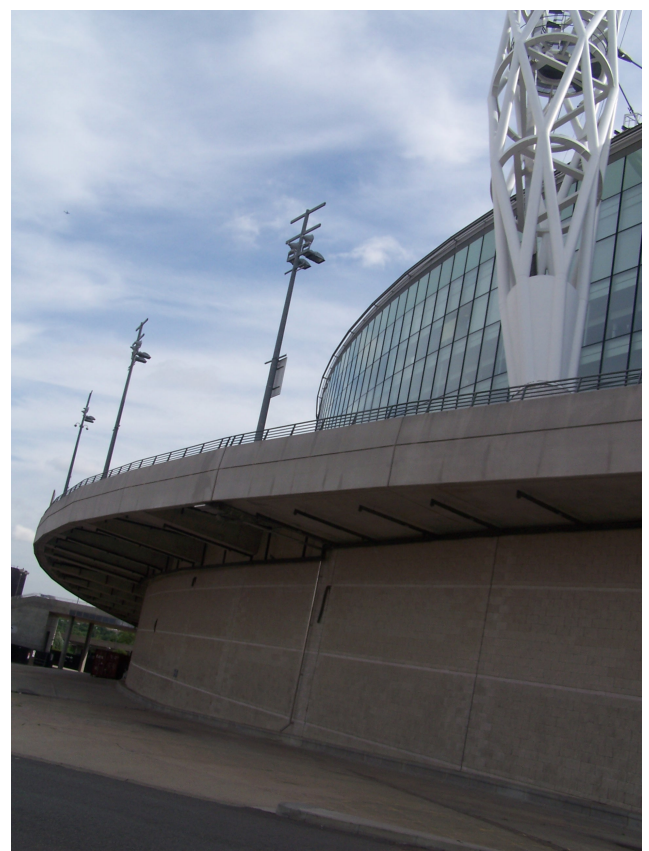

Figure 1 - The new Wembley with its new symbolic element.

English Heritage is the British government's lead body for the historical environment in England. In its Conservation bulletin of 2012 about "Sporting Heritage", Paul Velluet presented highlighted the interest of the towers. "Initial plans to retain or relocate the iconic twin towers were abandoned and these were included in the demolition". (English Heritage, 2012) After an examination of its architectural and historic interest, the old Wembley stadium has been completely demolished with the consent of Heritage Authorities in 2003. It was de-listed in March 2011 on the basis of this demolition and examination. Velluet adds that the new stadium is outstanding but the generously landscaped setting which English Heritage staff had hoped to see provided has not materialised. (English Heritage, 2012)

In this case economic factors were decisive for the destruction of the iconic Wembley twin towers, as these were no longer adapted to the new requirements, even though their bequest value was clear. The new building is not a multisport stadium; its landmark value is disputed. The tension between bequest and use values was resolved here through demolition. 


\section{Rome: The transformation of the Olympic stadium 1960 and Foro Italico}

The Foro Italico was completed following the end of World War II so as to accommodate the Olympic Games of 1960. After the Olympics, the National Olympic Committee issued an important conclusion about Foro Italico: "The venues that were prepared for the event have today become an ever-increasing attraction to the youth of Rome who frequent them with great enthusiasm, filled with the memories of the success of the Rome Olympiad". (OCOG, 1963)

The unity and integrity of the Foro Italico complex were respected for more than 50 years. The high quality of the buildings and their architectural values required special care so that any transformation of the place would at the same time conserve its qualities. In the eighties the city of Rome decided to transform the Olympic stadium at Foro Italico. A radical and negative transformation of the Olympic stadium was planned in 1990, through the construction of 40 meter high pillars inside the stadium and four other pillars on the edge of the stadium with a height of 52 meters. (ICOMOS, 1988) Political parties, environmentalists, and groups of citizens denounced this proposal. The height of some pillars was reduced in response. But the existing tribunes were radically transformed or demolished. "A radical and truly negative transformation of the Olympic stadium happened in 1990". (ICOMOS, 1988) Today a substantial change of scale and relationship between different parts can be noted on the site, as for example the relationship with Stadio dei Marmi (Picture 2). Moreover, adjacent urban growth crowds in around the site with little regulation.

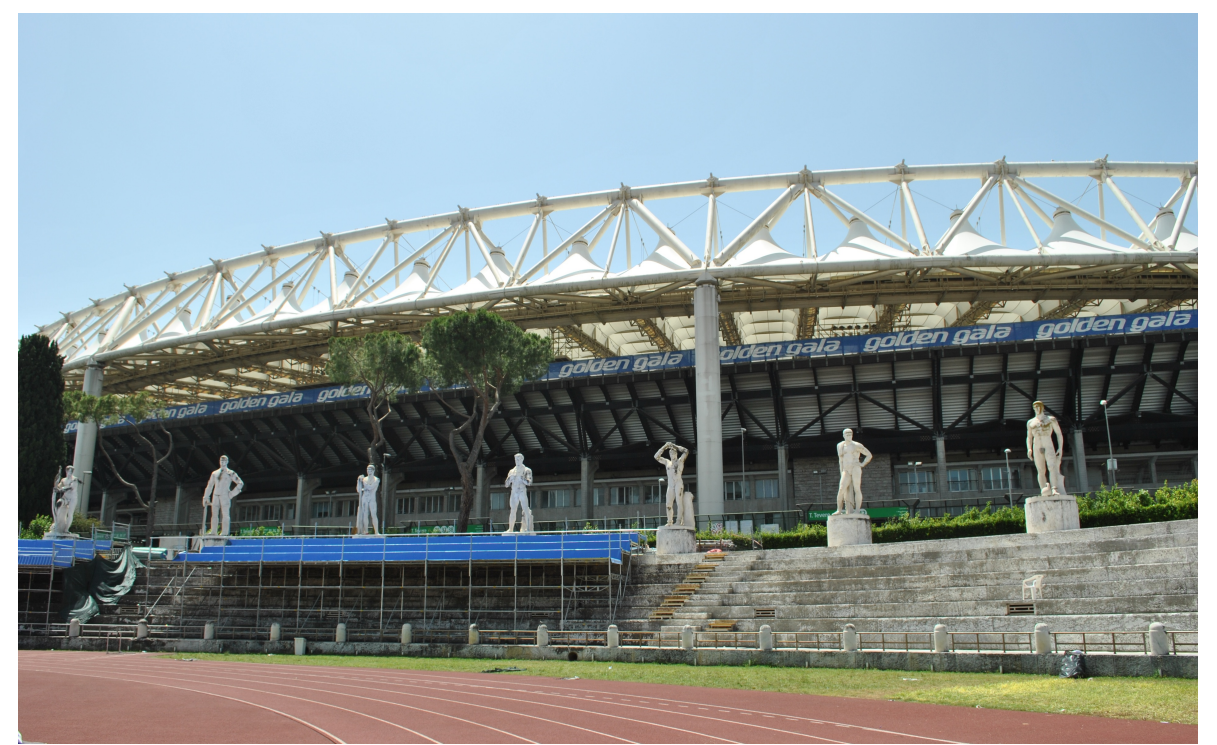

Figure 2 - The Olympic stadium of Rome after 1990 and Stadio dei Marmi

This brilliant example of modern heritage is solely protected through urban planning policy. (ICOMOS, 1988) Due to its high cultural relevance, Foro Italico is subject to monumental constraint of the Decree of 31 January 1989 pursuant to Law n.1089 of 1939 as well as landscape obligations pursuant to Resolution of the Regional Council of Lazio n. 10591 of 5 December 1989 "Valle del Tevere" pursuant to Law 1497 of 1939. It is also included in the New General Plan of the City of Rome as part of the Historical city area, as well in the "Charter for Quality". Foro Italico is referred to as a significant architectural, urban and environmental complex of buildings.

But at the end of the eighties the Olympic stadium was excluded from regulations related to monuments. The Foro Italico is today even more at risk, because it 
is undergoing heavy transformation works that are affecting both the free areas and the historic buildings. (Vittorini, 2008) "The CONI Servizi company developed a project, as yet only along general lines, but whose first results seem decidedly alarming, and pushes us to call for a clear, decisive, and urgent intervention from the institutions dedicated to conservation of the cultural landscape and architectural heritage of our country. This intervention requires a high-quality project, which is based on an awareness of the roots and unique history of Foro Italico, and which does not take the form of occasional acts of maintenance which simply distort the site's original characteristics". (DoCoMoMo, 2012) This declaration by DoCoMoMo - Italy confirms the need for a much better understanding of sport heritage characteristics.

In this case the integrity of the Olympic complex and the architectural values of some of its buildings have been altered even though none of the buildings were demolished. The principal cause of these alterations is related to the intended staging of new sporting events with new technical requirements. This pressure is now increased by the urban growth around the site. In this case the bequest value of the site was not given sufficient consideration through a specific legal protection, which is a clear difference with the previous case. This constitutes an example of the vulnerability of architectural and site composition when excessive weight is given to use values, especially given the technical requirements of different sports.

\section{Berlin: The political contamination of the Olympic stadium 1936}

The Olympic complex that hosted the Games of 1936 plays an important ongoing role in the city of Berlin, even though it was once one of the places most directly associated with the national-socialist regime. The Olympic stadium is characterised by a distinctive style and architectural composition. The setting of the stadium includes a modern garden, representative buildings and a historical green area named Grunewald.

The Office of Monument Protection of the state of Berlin decided to preserve the entire complex as a multi-functional area. Built in 1913 for the 1916 Olympics, rebuilt for the 1936 Olympics, listed in 1966, renovated for the 1974 football World Cup, reconfigured and roofed for the 2006 World Cup, the Olympic stadium of Berlin has witnessed a series of transformations over time. The fact that it is part of a larger listed area including a series of buildings, green spaces and sculptures is of particular interest.

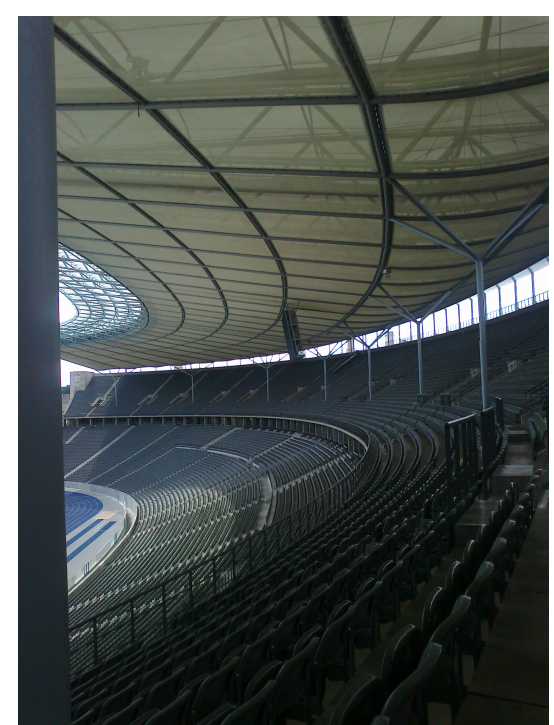

Figure 3 - The reconfigured and roofed Olympic stadium of Berlin for the World Cup in 2006 
The stadium is part of a "Special building land with green character", the definition of which provides that "In this category of special building land, at least $60 \%$ of the area shall remain open ground of a generally green character". The Olympic Grounds, with its Olympic Stadium and other sports facilities of city-wide importance as well as the adjoining "Waldbühne" (open air arena), are characterised by the special purpose of their buildings and facilities and by different types of large open spaces described in the Berlin Land Use Plan Brochure. (Heike et. al., 2005) The Berlin Land Use Plan (FNP) defines the distribution of land uses according to the strategic objectives of the city of Berlin. The Olympic site is probably one of the most significant monumental sports complexes of the 20th century in Europe. It was hence valued as "German Landscape" by local heritage authorities.

Berlin stadium is probably one of the best examples of the way sport and Olympics can be negatively contaminated by politics and ideological influences. This may explain why the environmental role and the preservation of landscape values in the urban context are so highly valorised in the conservation of this place. The bequest values of the site, related to an architectural style symbolic of a now discredited ideology, have been considered as a testimony of the dramatic history of the site. In this case the use value of the broader site was the key factor in heritage conservation.

These three cases show different manifestations of tensions between bequest and use values.

\section{The case of the six listed Olympic stadiums}

Studying Olympic stadium values through existing heritage official documents can help in understanding their particular and complex significance. Here below we present a study of listed Olympic stadium through a categorisation of values mentioned in official decisions justifying their listing. These official decisions were either provided by the international archives of ICOMOS, Paris or by the respective national heritage services. This included Stockholm, The Netherlands, USA, Berlin and its official site, Australia and its site, the UNESCO documents of the UNAM WCH, the New South Wales and its site, and the official site for the cultural heritage of the Russian Federation.

Three categories have been derived on the basis of the analysis of listing decisions: "Object", "Evolution" and "Context". The "Object" category provides information regarding the authoring, structure and shape of the stadium, and the relation of the stadium to the broader sporting complex within the host city. The "Evolution" category contains information about use after the completion of the Olympic Games and any changes in the stadiums. The "Context" category includes elements about the celebration of the Games and the significance of that heritage for the society at large.

\section{Description of modern Olympic stadiums listed as heritage}

As mentioned above, we analyse listed modern Olympic stadiums and ensembles. The Athens 1896 Panathenaic Stadium has been a National Architectural Monument since 1999 , but the present stadium is a reconstruction of the ancient one. A stadium was initially built in this place in $330 \mathrm{BC}$. In the second century BC it was lined with marble. The reconstruction of this stadium could be subject of further studies. It was not considered in our survey because it is not a contemporary facility intended to serve modern sporting requirements. London's Empire Wembley was listed as a National Monument Building in 1967 and delisted before its demolition in 2003. We analysed this stadium as an example of controversy. 
Currently there are six listed modern Olympic stadiums and two listed objects that are part of stadium ensembles (Table 1). The former are in Stockholm, Amsterdam, Los Angeles, Berlin, Melbourne and Mexico City. These Olympic stadiums are listed as (i) buildings (Stockholm, Los Angeles), (ii) a complex of buildings (Mexico City), (iii) a landscape (Berlin), or (iv) a place (Melbourne). Two stadiums (Moscow and Sydney) contain objects listed as monuments. These listed objects are a group of sculptures in the Olympic complex in Moscow, and the cauldron in the Sydney Olympic stadium. There are large differences in the procedures regarding the listing of monuments throughout the world. As an example, there is only one type of monuments in Germany. As the German states are directly responsible for the listing of monuments, there are only "state" monuments in Germany.

\begin{tabular}{|c|c|c|c|c|}
\hline & Host City & Object of listing & Level of Heritage & Type of Heritage \\
\hline 1 & Stockholm 1912 & Stockholms Stadion & Local & Historical Building \\
\hline 2 & Amsterdam 1928 & Olympisch Stadion & National & Architectural Monument \\
\hline 3 & $\begin{array}{l}\text { Los Angeles } 1932 \\
\text { and } 1984\end{array}$ & $\begin{array}{l}\text { Los Angeles Memorial Coliseum - } \\
\text { Olympic stadium }\end{array}$ & National & Landmark \\
\hline 4 & Berlin 1936 & $\begin{array}{l}\text { Olympiastadion, Olympic former Reich } \\
\text { Sports Field, Olympic Park with former } \\
\text { Deutsches Forum Sports and former } \\
\text { building of the racecourse Grunewald }\end{array}$ & $\begin{array}{l}\text { Local (In Germany, there } \\
\text { is only "state" heritage) }\end{array}$ & Landscape \\
\hline 5 & Melbourne 1956 & Melbourne complex & National & Place \\
\hline 6 & Mexico 1968 & $\begin{array}{l}\text { The Central University City Campus of } \\
\text { the Universidad Nacional Autónoma de } \\
\text { México (UNAM) }\end{array}$ & $\begin{array}{l}\text { International } \\
\text { (World Cultural Heritage) }\end{array}$ & Site \\
\hline a & Moscow 1980 & $\begin{array}{l}\text { Group of sculptures “Zemlya” (Земля) } \\
\text { and « Vada » (Вода) -1957; Leninu } \\
\text { (Ленину) - } 1960 \\
\text { Luzhniki Olympic Complex }\end{array}$ & National (federal) & Art Monument (statues) \\
\hline $\mathrm{b}$ & Sydney 2000 & The Sydney Olympic Park Cauldron & Local & Object (the popular fountain) \\
\hline
\end{tabular}

Table 1. Listed Olympic stadiums

The oldest listed stadium is the stadium of Stockholm; it is now listed as local heritage. The stadium of Amsterdam and that of Los Angeles are listed at the national level. The precinct of the Melbourne complex is listed as national heritage; the Australian Government also listed the Olympic Swimming Stadium (1956). The Olympic Park of Berlin is listed as city heritage. The heritage significance of the objects is considered of national value in the case of Moscow (for the Russian Federation) and of local value in the case of Sydney (for the State of New South Wales).

It can be seen from the above that there is a strong variance in the form of recognition (as building, ensemble, site or landscape) of Olympic heritage as well as about the significance of its value (local, national, international).

\begin{tabular}{|l|l|l|l|l|}
\hline & Host City & OG Year & Listing Year & Designator \\
\hline 1 & Stockholm & 1912 & 1990 & Swedish National Heritage Board (66) \\
\hline 2 & Amsterdam & 1928 & 1992 & Government - The Cultural Heritage Agency \\
\hline 3 & Los Angeles & 1932 & & $\begin{array}{l}\text { Proposed by the American Institute of Architects; } \\
\text { State preservation coordinator; University of South California }\end{array}$ \\
\hline 4 & Berlin & 1984 & 1984 & Probably the Berlin Ministry (Senatsverwaltung für Bauen und Wohnen) \\
\hline 5 & Melbourne & 1956 & 2005 & Heritage Council recommendation to the local Planning Authority \\
\hline 6 & Mexico City & 1968 & 2007 & UNAM, District Programme of Urban Development \\
\hline a & Moscow & 1980 & 1974 & Council of Ministers \\
\hline b & Sydney & 2000 & 2000 & New South Wales State Government \\
\hline
\end{tabular}

Table 2. Year of the hosted Olympic Games and year of Heritage nomination

Table 2 indicates the years of heritage nomination relative to the year of celebration of the Olympic Games. It highlights that there is a significant variation in 
the time span between the celebration of the Games and the listing of parts of the legacy.

Some stadiums and places were built before the awarding of the right to hold the OG, as for example the stadium for Melbourne. Those stadiums were then listed after the Olympics. There are stadiums built for the Games, as for example the stadiums of Stockholm and Amsterdam. The oldest Olympic Games with listed heritage are the Games of Stockholm in 1912. This modern stadium was listed as local heritage 78 years after the Games. The stadium of Amsterdam was listed 64 years after hosting the Olympic Games in 1928. In the case of the Moscow Olympic complex, the listed statues were built before hosting the games. The Games that influenced the construction of the Moscow stadium and its sports park were the OG of Helsinki in 1952. These Games were very successful for Russia (as the former USSR) and motivating for the development of Soviet sport in general. (Heike et. al., 2005)

It is interesting to mention the chronology of the stadium of Los Angeles. It hosted the Games in 1932 and was declared national heritage on the occasion of the Games in 1984, the second Olympic Games celebrated in the same stadium. This is a unique case in the history of the OG.

The size and physical dimensions of listed heritage are quite variable. The site of UNAM is 730 ha while the 8.5 tonne Sydney Olympic Games cauldron has an overall diameter of $10 \mathrm{~m}$.

The stakeholders involved in the listing process can be heritage authorities (councils, agencies, etc.), local planning and urban authorities, national architectural bodies (institutes, colleges, unions), universities and governmental entities. Local planning and urban authorities often play an active role in the designation. The involvement of local authorities denotes the large-scale impact and influence of the Olympic precincts. Universities are also involved commonly in the process, as historical research into sports buildings and sport complexes can be important, as well as the analysis of the educational potential of these facilities. By contrast, it is striking that sports authorities in none of the cases analysed here participated in the listing process, whether national sports bodies or the IOC. In the listing decisions that we consulted, these authorities never appeared as an active stakeholder, or as supplying information and support for the process.

As noted before, the staging of the Olympic Games is historically linked to the stadium's heritage significance. The results regarding the year of heritage nomination compared to the year of the OG celebration show that the average waiting time is around 52-53 years. In two cases the Games were the occasion for declaring the heritage nomination: Los Angeles 1984 and Sydney 2000 (the cauldron). The sole modern Olympic stadium to be declared World Cultural Heritage by UNESCO is the stadium of Mexico City, part of the listed site of UNAM. This site is characterized by a diversity of functions and building types. These are not only sports facilities. The multi-use of this site is contributing to "quality of life" in a much broader sense, one of the key factors in its nomination.

There is no relation between the level of heritage and the time that has elapsed since the celebration of the Games. For example the stadium of Stockholm waited 78 years to become a local heritage building. The UNAM site together with the Olympic stadium of Mexico City was declared WCH 39 years after the Games in 1968. 


\begin{tabular}{|c|c|c|c|c|c|c|c|c|}
\hline \multirow{2}{*}{ Stadium } & \multicolumn{3}{|c|}{ Object description } & \multicolumn{2}{|c|}{ Evolution description } & \multicolumn{3}{|c|}{ Context description } \\
\hline & Authoring & $\begin{array}{l}\text { Structure/ } \\
\text { Shape/Style }\end{array}$ & $\begin{array}{l}\text { Sport complex/ } \\
\text { Urban context }\end{array}$ & Post OG use & Changes & OG celebration & $\begin{array}{l}\text { Political/ } \\
\text { Social/ } \\
\text { Cultural/ } \\
\text { Historical v. }\end{array}$ & Significance \\
\hline Stockholm & Torben Grut & $\begin{array}{l}\text { Model for } \\
\text { other } \\
\text { stadiums } \\
\text { Unique facility } \\
\text { for } \\
\text { many years } \\
\text { Knowledge } \\
\text { and } \\
\text { experience } \\
\text { source } \\
\text { National } \\
\text { romantic } \\
\text { spirit } \\
\text { Material } \\
\text { authenticity } \\
\text { Valuated } \\
\text { towers and } \\
\text { walls }\end{array}$ & & $\begin{array}{l}\text { Peace for } \\
\text { sport } \\
\text { events } \\
\text { Concerts } \\
\text { to weigh the } \\
\text { antiquarian } \\
\text { values with } \\
\text { the local } \\
\text { needs } \\
\text { of a } \\
\text { functioning } \\
\text { rena for a } \\
\text { athletics and } \\
\text { football }\end{array}$ & $\begin{array}{l}\text { Changes and } \\
\text { restoration with } \\
\text { authorization } \\
\text { Electrical } \\
\text { powering } \\
\text { Fire safety } \\
\text { Roof } \\
\text { Realignment } \\
\text { Modernization } \\
\text { Amplification }\end{array}$ & $\begin{array}{l}\text { Olympic } \\
\text { complex } \\
\text { Reminding } \\
\text { directly } \\
\text { to the IX OG } \\
\text { Population } \\
\text { rescued } \\
\text { the Olympics }\end{array}$ & $\begin{array}{l}\text { Place of } \\
\text { records } \\
\text { ( } 83 \text { world } \\
\text { records in } \\
\text { athletics) } \\
\text { Culture, } \\
\text { historic }\end{array}$ & Antiquarian \\
\hline Amsterdam & $\begin{array}{l}\text { Jan Wils } \\
\text { (Amsterdam } \\
\text { school); Inspired } \\
\text { by } \\
\text { Frank Lloid } \\
\text { Wright } \\
\text { Initial plan of } \\
\text { Berlage }\end{array}$ & $\begin{array}{l}\text { Inspired by } \\
\text { Olympic ideals } \\
\text { Expressionist } \\
\text { style } \\
\text { with plastic- } \\
\text { geometric } \\
\text { forms and } \\
\text { striking } \\
\text { appearance } \\
\text { Dominant core } \\
: \\
\text { stadium and } \\
\text { Marathon } \\
\text { Tower }\end{array}$ & $\begin{array}{l}\text { One of six sport } \\
\text { facilities } \\
\text { ( } 1 \text { demolished) } \\
\text { The main part of } \\
\text { the Olympic } \\
\text { Stadium ensemble } \\
\text { Commemorative } \\
\text { plaque }\end{array}$ & 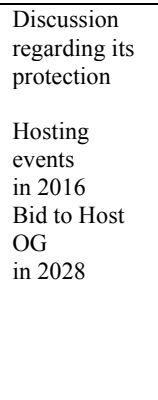 & $\begin{array}{l}\text { Partially } \\
\text { modified } \\
\text { after the OG } \\
\text { then returned } \\
\text { and } \\
\text { reopened to the } \\
\text { city } \\
\text { Protected }\end{array}$ & $\begin{array}{l}\text { Decisive role of } \\
\text { the } \\
\text { OG } \\
\text { for its } \\
\text { construction }\end{array}$ & $\begin{array}{l}\text { One of the first } \\
\text { outdoor Sport } \\
\text { facilities } \\
\text { Culture, sports, } \\
\text { architecture, } \\
\text { construction } \\
\text { and } \\
\text { urban- } \\
\text { historical value } \\
\text { Preserved the } \\
\text { memory of the } \\
\text { OG, } \\
\text { of the national } \\
\text { sports }\end{array}$ & $\begin{array}{l}\text { Sport, leisure, hospital } \\
\text { and recreation }\end{array}$ \\
\hline Los Angeles & $\begin{array}{l}\text { J.\&D.Parkinson, } \\
\text { two } \\
\text { of the most } \\
\text { prominent } \\
\text { LA architects of } \\
\text { the } \\
\text { early } 20^{\text {th }} \text { century } \\
\text { distinguished } \\
\text { architects }\end{array}$ & $\begin{array}{l}\text { One of the first } \\
\text { outdoor sport } \\
\text { facilities of the } \\
\text { world } \\
\text { Key example } \\
\text { of the } \\
\text { architectural } \\
\text { work } \\
\text { Peristyle } \\
\text { façade } \\
\text { Eclectic and } \\
\text { transitional } \\
\text { architecture }\end{array}$ & $\begin{array}{l}\text { Sports field } \\
\text { located in } \\
\text { Olympic Park } \\
\text { Other dispersed } \\
\text { facilities } \\
\text { City planning } \\
\text { concept work }\end{array}$ & $\begin{array}{l}\text { Use before } \\
\text { and } \\
\text { after the OG } \\
\text { Sport events } \\
\text { Civic events } \\
\text { Patriotic } \\
\text { rallies }\end{array}$ & $\begin{array}{l}\text { Enlarged } \\
\text { Modifications } \\
\text { Reduced sites } \\
\text { Regular changes } \\
\text { "It appears so } \\
\text { much } \\
\text { like its original } \\
\text { self" }\end{array}$ & $\begin{array}{l}\text { The first } \\
\text { Olympic } \\
\text { stadium to host } \\
\text { two } \\
\text { modern summer } \\
\text { OG } \\
\text { Notable and } \\
\text { influent } \\
\text { Well attended } \\
\text { and } \\
\text { publicized } \\
\text { games } \\
\text { Opening and } \\
\text { closing } \\
\text { ceremonies, } \\
\text { Track and field } \\
\text { events, } \\
\text { gymnastic; } \\
\text { field hockey } \\
\text { final; } \\
\text { demonstration, } \\
\\
\text { equestrian } \\
\text { jumping } \\
\text { finales; start and } \\
\text { finish } \\
\text { point of the } \\
\text { marathon }\end{array}$ & $\begin{array}{l}\text { Historical, } \\
\text { Social, } \\
\text { Political } \\
\text { Success of the } \\
\text { OG in } \\
\text { a global crisis } \\
\text { Number of } \\
\text { innovations } \\
\text { Anti Olympic } \\
\text { Sentiment in } \\
\text { California } \\
\text { Civic emblem: } \\
\text { LA was } \\
\text { transformed } \\
\text { from a } \\
\text { small western } \\
\text { city into a } \\
\text { world } \\
\text { metropolis }\end{array}$ & $\begin{array}{l}\text { Architectural } \\
\text { Engineering structure } \\
\text { National and internati } \\
\text { historical significance }\end{array}$ \\
\hline$\underline{\text { Berlin }}$ & $\begin{array}{l}\text { Otto March (first } \\
\text { venue) } \\
\text { Werner March } \\
\text { C. Mertz } \\
\text { (reconstruction) } \\
\text { Heinrich Friedrich } \\
\text { Wiepking - } \\
\text { Jürgensmann }\end{array}$ & $\begin{array}{l}\text { Significant } \\
\text { architectural } \\
\text { and } \\
\text { engineering } \\
\text { structure }\end{array}$ & $\begin{array}{l}\text { "German } \\
\text { Landscape" } \\
\text { Monumental } \\
\text { buildings of the } \\
\text { Olympic Park, } \\
\text { Sequence of } \\
\text { squares }\end{array}$ & & $\begin{array}{l}\text { Renovated and } \\
\text { modernized }\end{array}$ & Importance & $\begin{array}{l}\text { The system } \\
\text { recalls } \\
\text { the close links } \\
\text { between sport } \\
\text { and } \\
\text { power } \\
\text { Abuse of sport } \\
\text { for a criminal } \\
\text { ideology }\end{array}$ & $\begin{array}{l}\text { Architectural } \\
\text { Historic }\end{array}$ \\
\hline Melbourne & $\begin{array}{l}\text { Public work } \\
\text { department }\end{array}$ & $\begin{array}{l}\text { Part of Yarra } \\
\text { Park } \\
\text { (for public } \\
\text { recreation } \\
\text { since 1860) }\end{array}$ & $\begin{array}{l}\text { One of four } \\
\text { sport facilities }\end{array}$ & $\begin{array}{l}\text { Site of many } \\
\text { major } \\
\text { sporting } \\
\text { events } \\
\text { There is a } \\
\text { continuity of } \\
\text { use }\end{array}$ & $\begin{array}{l}\text { Extensions and } \\
\text { changes (roof, } \\
\text { interiors, } \\
\text { façade) } \\
\text { Planning } \\
\text { scheme } \\
\text { protection }\end{array}$ & $\begin{array}{l}\mathrm{I} 1^{\text {st }} \mathrm{OG} \text { in the } \\
\text { Southern } \\
\text { Hemisphere } \\
\text { Soccer, athletics }\end{array}$ & $\begin{array}{l}\text { Historic place } \\
\text { Egalitarian } \\
\text { image as } \\
\text { 'the people's } \\
\text { ground' } \\
\text { Sporting } \\
\text { achievements }\end{array}$ & $\begin{array}{l}\text { Events, Processes } \\
\text { Social value } \\
\text { Significant people }\end{array}$ \\
\hline
\end{tabular}




\begin{tabular}{|c|c|c|c|c|c|c|c|c|}
\hline & & & & & & & $\begin{array}{l}\text { Symbolic } \\
\text { home of } \\
\text { Football } \\
\text { The first } \\
\text { cricket club } \\
\text { since } 1853\end{array}$ & \\
\hline Mexico City & $\begin{array}{l}\text { Relevant } \\
\text { architects } \\
\text { Augusto Perez, } \\
\text { Jorge } \\
\text { Bravo, Raul } \\
\text { Salinas } \\
\text { Mario Pini, master } \\
\text { plan } \\
\text { Diego Rivera, } \\
\text { plastic art }\end{array}$ & $\begin{array}{l}\text { Unique shape } \\
\text { One of the } \\
\text { most } \\
\text { praised } \\
\text { architectural } \\
\text { constructions }\end{array}$ & $\begin{array}{l}\text { Part of the main } \\
\text { buildings of the } \\
\text { Campus } \\
\text { Functional } \\
\text { and environmental } \\
\text { values }\end{array}$ & & Preservation & $\begin{array}{l}\text { Importance } \\
\text { First OGs in } \\
\text { Latin America }\end{array}$ & $\begin{array}{l}\text { Outstanding } \\
\text { universal value } \\
\text { from the point } \\
\text { of } \\
\text { view of } \\
\text { sciences, } \\
\text { arts and } \\
\text { humanities }\end{array}$ & $\begin{array}{l}\text { Modern Architecture } \\
\text { Historicist Regionalis } \\
\text { Plastic Integration }\end{array}$ \\
\hline Moscow & $\begin{array}{l}\text { Famous artists } \\
\text { Vera Moukhina } \\
\text { M.G.Manizer } \\
\text { (architect - I. } \\
\text { Rojin ) }\end{array}$ & $\begin{array}{l}\text { Group of } \\
\text { Statues }\end{array}$ & $\begin{array}{l}\text { Located in "Aley } \\
\text { of } \\
\text { Prestige" at } \\
\text { Luzhniki Olympic } \\
\text { Complex }\end{array}$ & Green Park & $\begin{array}{l}\text { Preservation } \\
\text { Conservation }\end{array}$ & $\begin{array}{l}\text { Exiting before } \\
\text { the OG }\end{array}$ & Cultural & Monumental art \\
\hline $\begin{array}{l}\text { Sydney } \\
\text { (cauldron) }\end{array}$ & $\begin{array}{l}\text { Michael Scott - } \\
\text { Mitchell } \\
\text { Tzannes } \\
\text { Associates }\end{array}$ & $\begin{array}{l}8.5 \text { ton } \\
\text { perforated, } \\
\text { corrugated } \\
\text { shell }\end{array}$ & $\begin{array}{l}\text { Relocated to the } \\
\text { C. Freeman Park }\end{array}$ & $\begin{array}{l}\text { Current use as } \\
\text { a fountain }\end{array}$ & $\begin{array}{l}\text { Change of } \\
\text { position : } \\
\text { removed } \\
\text { northern part of } \\
\text { the stadium }\end{array}$ & $\begin{array}{l}\text { The Millennium } \\
\text { OG } \\
2^{\text {nd }} \text { time } \\
\text { OG in the } \\
\text { southern } \\
\text { Hemisphere } \\
\text { Opening } \\
\text { ceremony } \\
\text { Popularity } \\
\text { around } \\
\text { the world }\end{array}$ & $\begin{array}{l}\text { Proud of the } \\
\text { success of the } \\
\text { OG } \\
\text { Couldron: one } \\
\text { of the } \\
\text { most } \\
\text { memorable } \\
\text { images }\end{array}$ & $\begin{array}{l}\text { State historic, Social } \\
\text { Rarity, Representative } \\
\text { Integrity, Aesthetic }\end{array}$ \\
\hline
\end{tabular}

Table 3. The listed Olympic stadiums with information from official listing decisions

\section{Categorisation of heritage values identified in official listing decisions}

Table 3 provides information drawn from official-listing decisions and organised into the three categories "Object", "Evolution" and "Context". The "Object" category covers the authoring, the structure and the shape, the relation of the stadium to the broader sporting complex within the host city. The "Evolution" category covers use after the Olympic Games and any changes made to the stadiums. The "Context" category addresses issues related to the role of the Games celebration and the definitions of the area of significance.

\section{A-Values related to the object and its physical context}

The "Object" category typically relates to bequest values as defined above.

In several cases the authoring of the stadium is the work of "prominent and distinguished architects" (Los Angeles) or pioneers in their profession. The architectural achievements of the building are characterised as a "key example of the architectural work" (Los Angeles), unique work, relevant work or a "model for other stadiums" (Amsterdam). Berlage was the author of the initial plan for the Amsterdam stadium. Frank Lloyd Wright appreciated the Olympic stadium of Mexico City. The "plastic integration" of UNAM was highly valued by ICOMOS. Renowned artists such as Diego Rivera worked on those major buildings.

The structures and the shapes are appraised in heritage documents as important, significant, modern and/or unique. Stadiums are often spectacular and modern buildings, as for example in the case of the stadium of Stockholm, which was considered as a "unique facility" for many years. The listed stadiums are part of a multipurpose area and the stadium space is predominantly used for multi-sport.

It should be noted that there is a variety of architectural styles identified in the descriptions of the different stadiums: modern, historicist, expressionist, regionalist, eclectic, transitional, even architecture with "national romantic spirit" in the case of the Stockholm stadium. Pure architectural styles do not predominate in the listed stadiums. Style itself does not appear as the most determinant value. The presence of 
compositional architectural elements and accents like towers, main entrances, or arches is often mentioned in decisions. Those elements are not present in the current configurations of stadiums.Stockholm stadium is a testimony to a certain know-how and experience, as it was built with bricks, allowing singular elements and details to be created. The "authenticity of materials" (Stockholm) is appreciated, as well as the special design of architectural elements like towers, walls, arches and main entrances.

The documents analysed often refer to the fact that stadiums are part of groups of sports arenas, buildings, sites, or parks. Six stadiums and stadium ensembles are located in green parklands regarded as part of their value. The name "Olympic Park" appears in the case of Los Angeles stadium. Sculptures, art works and commemorative plaques and objects are also present. Olympic stadiums and the OG help to develop recreational areas (new sport and recreation centres). This functional and environmental role is valued in the case of Mexico City as a source of "quality of life". The presence of "sequences of squares" (a sign of permeability and dialogical spaces) is highlighted in the case of Berlin. The interaction of the sports complex with buildings serving other functions favours the use of the site with added social values.

\section{$B$-Values related to the evolution of the stadium}

The category "Evolution" addresses all values related to post-OG use and observed changes since the event, and hence typically refers to the use values defined above.

In the post-OG phase, the listed stadiums and sites have often been the venue for many sporting events, historical, political and civic events, as well as serving as home to one or more local sporting teams. The stadium of Amsterdam was "saved from demolition" by public fundraising motivated by the idea of preserving national memories.

All the stadiums and sites analysed underwent changes before, during, or after the Games. In several cases new major events after the OG induced important changes (external and internal). Some stadiums have been enlarged, reconstructed, modified, partially modified, extended, modernised, and even removed. Very often, changes took the form of reducing seating capacity (for security and comfort), adding or resurfacing running tracks, or covering tribunes. The term "preservation" as an objective is mentioned in the case of Mexico City UNAM campus and its Olympic stadium. Rehabilitation measures were undertaken in Stockholm as approved by the heritage authority. Here the challenge was to retain "the original appearance" or to achieve a balance "between innovation and tradition". There have been many and important changes in the listed modern Olympic stadiums. These changes were viewed in some cases as an element in the value of these sites, giving them a historical depth. This was especially the case of the stadium of Melbourne. In other cases like that of Stockholm, these changes were judged as negative in their impact on stadium integrity.

\section{C-Contextual values related to sport symbolism and socio-political dimension}

In the "Context" category we gathered all aspects related to the celebration of the Olympics, sporting symbolism, history and performances associated with the stadium. This is necessarily a very specific category, directly related to the Olympic legacy.

All analysed documents highlight the importance of the "Celebration of the Games" as a "unique event" for the hosting city. The Games history itself is an important source of value for these sites. Celebrating the Millennium Games for example increased the impact of the Games of the XXVII Olympiad for Sydney in 2000. The first hosting of the Olympics by a country or their staging for a second time in the same place were considered relevant aspects in relation to heritage designation. 
The latter was the case for the Los Angeles stadium. The sporting performances during the Games and the TV audience are also evoked as evidence of the value of stadiums. Some stadiums are directly related to major historical events. This is clearly so in the case of the Mexico City stadium, associated with the silent protest of American athletes against the treatment of black people. Also, it was there that a Mexican athlete became the first woman to light the cauldron. The multisport use and the ceremonies as social events are also considered for their value. The "civic groups effort" to achieve the construction for the OG as well the political effort to prepare the Games are considered as relevant in several cases, as for example in Amsterdam and Los Angeles.

All stadium descriptions refer to "political/social/historical" values. Social and political values are evaluated in terms of civic effort and support, political effort (or consensus), place where political events occurred, status as "civic emblem", spontaneous public support. Issues like "to serve the people" or status as an example of "civic achievement" are mentioned in the Los Angeles stadium documentation. "National pride" is mentioned in the case of the Sydney 2000 OG. Stadiums can also be considered as a "place of historical events", as for example in the Melbourne documents. The value of "place of records" highlights sport performance, place of event (sport, social, cultural, political) and "place of memory". The movement to conserve the Olympic stadium is strongly related to preservation of national sporting memory in the case of Amsterdam. Innovation in the conduct of certain sporting competitions at a particular Games is also pinpointed in some decisions.

To serve the people, to achieve civic objectives, to be unique or relevant, to build national image or create urban models (as for example "the German landscape") or sites of "quality of life" (Mexico City) stood out due to the performance during the OG.

The social and political significance of the Games (tangible and intangible) is often addressed as an element of value of Olympic heritage, beyond specific aspects related to sport performance and audience.

\section{Prevailing values in Olympic stadium heritage and their specific interaction}

It can be observed from Table 3 that prevailing values in stadium heritage are context values related to sport. Cultural and symbolic values mentioned in listing decisions usually refer to values specific to sporting achievements. As part of the values related to sport, the historical chronology of the Games is mentioned in most listing decisions. Most decisions refer to the success of the Olympiads as an event or as sporting performances. This contributes to the significance of the stadium. Other sporting events can also contribute to the importance of the facilities.

As regards the object itself, it can be noted that aesthetic values do not appear as the most important ones in listing decisions. Although prominent architects designed the six listed stadiums, architectural style is not often referred to in the documents. The authenticity of the site is obviously a factor in the listing. This facilitated the rehabilitation of some stadiums, such as the Stockholm stadium. The recreational quality of the spaces, the quality of ensembles and sites as green spaces, are also part of heritage values. Recreational values are mentioned in terms of post Games use. The site of UNAM and the Olympic stadium of Mexico City provide "quality of life" to citizens and visitors.

All listed stadiums have been modified, whether after hosting the Games or before, if they were already in existence then. They have witnessed changes as modernisation, enlargement or new coverings. The evolution of sporting standards and the requirements of new events, or simply the physical deterioration of the stadiums, 
can explain the need for this. It can be seen that these adaptations often became significant elements justifying the listing of some stadiums, even though this aspect is not often highlighted as a specific heritage value of the sporting and Olympic heritage.

Economic factors do not appear as a relevant element in the decisions, even though these are usually considered as part of use values. Use values in some cases can be a risk factor for the integrity of the site or for the architectural values. In the case of Rome, the Italian heritage authorities suggested a special policy plan for protection. The dialogue with the environment was an essential dimension of public landmarks inherited from antiquity, when the Olympic stadium was conceived in a compatible way with the values of the Olympic Games.

The success of the Olympic Games, the popularity of the event and its uniqueness and rarity play an important role in stadium heritage nomination at local, national and world levels. The observed relationship between the Olympic stadium significance and the success of the OG confirms the interdependence between the tangible and the intangible values in listed stadiums. But the intangible values of modern Olympic Games are not evoked as aspects of heritage. The human effort to prepare the Games is sometimes highlighted as context values. Several official descriptions of the listed stadiums evoke the value of "Prestige". We can see this value in the typology of Frey from 1997.

These results show that when both use and bequest values are duly taken into consideration, heritage may have a multiplicative effect on values related to sport. Some bequest values can help a successful adaptation of the stadium, contributing to an increase of its use values. At the opposite, some adaptations of stadiums necessitated to preserve or enhance use values can bring additional bequest values to the stadiums.

\section{Can cultural heritage add value to sport facilities and sites?}

The specific interactions of tangible and intangible values (the stadium, place, site, park and the Olympic Games as event) deserve more detailed study. Research needs to take into account changes in the selection criteria for cultural heritage. While initially historic and artistic values were the only parameters, other aspects have now been added: cultural value, the identity of the place and the capacity of the object to interact with memory. (Heike et. al., 2005) It is important to note that sporting venues can link people to places and past events in a uniquely powerful way. (Abercrombie, 2012) The recognition of uniqueness of places, their potential cultural dimension is directly connected with foundations of a self-sustaining regeneration strategy. (Wansborough and Mageean, 2000) The Olympics may be most appreciated for the large urban regeneration projects they initiate, as in the case of London. (Long, 2008)

The cases of listed heritage stadiums show the existing tension between bequest and use values in the case of sport facilities. Use values are often signalled as an important element of heritage for sport.

Another particularity of stadiums is that bequest is not limited to aesthetics. The societal role is far more important, recognised as "quality of life" and "recreation" among other qualities. After an Olympic Games, several parks created for the occasion of the Games may be turned into a large recreational urban area, providing space for cultural events.

Olympic stadium preservation should not overlook some specific elements characteristic of sport facilities. Otherwise some sport values may not be fully taken into consideration, as for example the intangible value related to the Games. 
Use values could be enhanced through specific tourism programs. The existing World Union of Olympic Cities (www.olympiccities.org) could play a role in the process, especially if Stadiums become part of a larger network of heritage sport facilities.

Education and research also contribute to identifying bequest values. Issues regarding needs in the context of academic education and research, and relating to the domain of emblematic sports facilities, are a natural fit with heritage studies. As mentioned above, universities have played a role in the heritage designation processes in many cases. The need for knowledge in the field of emblematic sport facilities and events is clear.

Most importantly, the value of the 24 Olympic stadiums as a historic ensemble was not mentioned in any of the listing decisions. Considering the ensemble of Olympic stadium sites as a unique heritage in its own right would certainly make sense under UNESCO criteria for World Heritage designation. This would help to increase the protection of individual buildings that are now considered of local significance. It may set a threshold for new facilities, like football arenas. It would represent a clear challenge for cities engaging in the Olympic Games, considering a possible listing as part of a network of heritage sites as soon as the design stage of the stadium.

Some cities express interest in staging the Olympics after having hosted the Games years before. In these cases Olympic bids could be pitched to include commitments to heritage conservation and enhancement. Tokyo, which will host the Games in 2020, has provided one example of such a possibility. Their bid project for the city presented at the $125^{\text {th }}$ IOC Session in Buenos Aires includes the concept "heritage zone", a reference to the site of the Olympic Games of 1964.

In a special bulletin dedicated to sporting heritage, English Heritage argued that statutory designation would not be the best approach to conserving sporting heritage. The challenge remains to retain and encapsulate memories in new uses. Safeguarding memories is truly important, but we are of the view that there is a certain danger to planning and designing new sports venues without the vision of heritage values as part of the design process.

\section{Conclusions}

This paper focused on the Olympic stadium heritage values and their cultural significance. It has been introduced by an analysis of controversies about the conservation/transformation of three heritage stadiums: Wembley, Rome and Berlin. The strength of these controversies highlighted the tension between bequest and use values in the conservation of Olympic stadiums.

Our analysis was then based on a detailed analysis of six listed Olympic stadiums. Heritage values of these six stadiums have been categorized, highlighting the need for specific criteria for evaluating Olympic heritage and sporting heritage more broadly. This analysis shows that the listed Olympic components differ in size, in type (building, place, site, landscape or simple objects part of the stadium ensembles) and level of heritage (local, national, international). Only one modern stadium has been declared World Cultural Heritage, as part of a multifunctional site. It is interesting to observe that in several cases regional and urban planning institutions have promoted the nomination of a stadium as heritage. It is surprising, therefore, that sport institutions or organisations have refrained from becoming part of this process. 
We then presented heritage descriptions taken from the official texts, and grouped them into three principal categories (object, evolution and sporting context). These descriptions consider classical requirements of heritage values typologies. They refer to the importance of the authoring, the authenticity of materials and the innovative structures or the venue model. Even so, the architectural style is not the most valued characteristic in such evaluations. The presence of elements of value such as towers or main entrances or other symbolic features are more significant. Some descriptions specially valued the multifunctional use of listed sites. More generally, the surroundings play an important role in a stadium's significance. This is probably a reflection of participation by regional and urban planning bodies in the heritage designation process.

On the other hand the preparation and the celebration of the Olympic Games are contextual elements that play a decisive role in the stadium's significance, bringing several added intangible values. The efforts to organise the event, to plan large-scale innovative buildings and create parks for recreation are some of the evoked values that give specific significance to the Olympic stadium. The success of the event itself is very important, for example in terms of setting new sporting records, as well as the popularity, but there is also the rarity of the Games, the additional social or historic events, the citizen participation and the political support surrounding the celebration of Olympic Games.

One the most frequently detected difficulties in stadium conservation are with the changes that all stadiums experience under the pressure of various technical and functional requirements. Strict conservation is neither always possible nor advisable, especially when we consider the exceptional character of the OG. Interestingly this is clearly reflected in the designation process that, in several cases, refers to these evolutions and adaptations as a relevant feature of these sites. The continuous use of OG Stadiums for other sport competitions could hence be considered as a supplementary source of significance and value.

OG Stadiums appear as great testimonies of the evolution of sport and its status for past and present societies. They should be considered as exceptional heritage, both through the international nature of the event they welcome and through their location all across the globe. The history of architecture and sport's history are clearly interwoven in the evolution of their design over time and their further adaptations and reuse after the celebration of the Games. This should plead for considering the entire ensemble of existing 24 Olympic stadiums as World Cultural Heritage.

\section{Acknowledgements}

Special thanks for the precious help to the ICOMOS Office - Paris, DoCoMoMo Italy, the Nederland (Amsterdam), Stockholm, Berlin, England (London), Australia (Melbourne), USA (Los Angeles) and New South Wales (Sydney) Heritage units and experts, as well as to the library of the University of Liege, the Library of the Olympic Museum, Lausanne, and the Library of the University of Lausanne.

\section{References}

Abercrombie, G. "Repositories of memory". In Sustaining Memory. Sporting Heritage, edited by Gemma Abercrombie, Conservation bulletin. Issue 68, 2. London: 2012. 
Avrami, E., R. Mason and M. de la Torre, eds. Values and Heritage Conservation. Research Report. Los Angeles: The Getty Conservation Institute, 2005.

Bithas, K. and P. Nijkamp. "Sustainable Development and Monument Conservation Planning: A Case Study on Olympia". ICOMOS (Central Cultural Fund Publication. 133) in: "Economics of conservation" (1993): 98-115.

Bolz, D. "Creating Places for Sport in Interwar Europe. A Comparison of the Provision of Sports Venues in Italy, Germany and England". The International Journal of the History of Sport, 29:14 (2012): 1998-2012. doi: 10.1080/09523367.2012.677825.

Bolz, D. "Welcoming the World's Best Athletes: An Olympic Challenge for Post-war Britain". The International Journal of the History of Sport, 27:6 (2010) : 10061028. doi: 10.1080/09523361003656159

Bolz, Daphné. Les arènes totalitaires. Hitler, Mussolini et les jeux du stade, Paris : CNRS Editions, 2008.

Casciato, M. "Sport and Leisure in Rome from the Fascist years to the Olympic Games", in ICOMOS, Nationalkomitee der Bundesrepublik Deutschland eds. Sport Sites Culture, ICOMOS Journal of the German National Committee XXXVIII (2002): 29-36.

Charkiolakis, N. " Sport, Sites, Cultures", in ICOMOS, Nationalkomitee der Bundesrepublik Deutschland (ed.), Ancient Greek Stadia, ICOMOS Journal of the German National Committee XXXVIII, (2002): 11-14.

Chatziefstathiou, D. and Ian Henry. "Hellenism and Olympism: Pierre de Coubertin and the Greek Challenge to the Early Olympic Movement", Sport in History, 27:1, (2007): 24-43, doi: 10.1080/17460260701231034.

Delsahut, Fabrice. Les hommes libres et l'Olympe : Les sportifs oubliés de l'histoire des Jeux Olympiques. Paris : L'Harmattan, 2004.

English Heritage's Advice Report. Wembley Stadium, Olympic Way. Wembley: English Heritage, 2012.

Gammon, S., Ramshaw, G. and Waterton, E. "Examining the Olympics: heritage, identity and performance". International Journal of Heritage Studies, Vol. 19, No. 2 (2013) : 119-124. url : http://dx.doi.org/10.1080/13527258.2012.687395 .

Gold, John and Margaret Gold, eds. Olympic Cities City Agendas, Planning and the World's Games 1896-2016. Second edition, London: Routledge, 2011.

González-Varas, Ignacio. Conservación de bienes culturales, Teoría, historia, principios y normas. Madrid: Manuales Arte Cátedra, 2005.

Gratton, Ch. and H. Preuss. "Maximizing Olympic Impacts by Building up Legacies", The International Journal of the History of Sport, 25:14, (2008): 1922-1938, doi: 10.1080/09523360802439023.

Haman, M. "Les routes des arènes et des stades en Europe et en Mediterrannée: des siècles d'architecture, de sport et de spectacle" in ICOMOS Journals of the German National Committee. XXXVII. ICOMOS Germany, (2002): 75-77.

Heicke, R., B. Roesrath and H. Sauer. "Berlin Land Use Plan", Senatsverwaltung für Stadtentwicklung Referat. Berlin: Spath \& Nagel, (2005).

ICOMOS. Decision - 13COM XV.A - The World Heritage Committee: The ICOMOS recommendation, World Heritage list 517, 1988.

ICOMOS. Approved report of the State Party: 1250 University City (Mexico). Campus of the Universidad Nacional Autónomade México: UNAM, 2007.

IOC, Olympic Charter. Lausanne: International Olympic Committee, 2013. 
Kairamo, M. "The renovation of the Olympic Stadium of Helsinki". ICOMOS, $12^{\text {th }}$ General Assembly. Monuments and sites. Finish National Commette of ICOMOS. (1999): 95 - 97.

Kiuri, Miranda. Estadio olímpico, espacio cultural. Un lugar de la memoria. Madrid: UCJC, 2009.

Kiuri, Miranda. "La Memoria Olimpica." ("The Olympic Memory"), PhD diss., UCJC co-directorship UPM, Madrid, 2007.

Kiuri, M., and S. Reiter. "Olympic stadium design: past achievements and future challenges". ArchNet-IJAR: International Journal of Architectural Research, 7, issue 2 (2013): 102-117.

Kiuri, M., and J. Teller. "Olympic stadiums in their urban environment: A question of design and cultural significance". The Journal of Cultural Heritage Management and Sustainable Development, 2, (2012): 115-129

Kiuri, M., and J. Teller. "The Stadium of Olympia, from the perspective of the dialogical architecture". Arquitectonics: Mind, Land and Society, 26: in press.

Kluge, Volker. Olympiastadion Berlin. Berlin: Das Neue Berlin, 2009.

Liao, H. and A. Pitts. "A brief historical review of Olympic urbanisation". The International Journal of the History of Sport, 23 n. 7, (2012): 1233-55.

Long, Judith G. Review of Olympic Cities: "City Agendas, Planning, and the World's Games", 1896-2012.Town Planning Review, 2008.

Marcotte, P. and L. Bourdeau. "Is the World Heritage label used as a promotional argument for sustainable tourism?" Journal of Cultural Heritage Management and Sustainable Development, 2 issue 1 (2012) : 80 - 91.

Mason, R. "Assessing values in conservation planning: methodological issues and choices", in de la Torre, M. ed., Assessing the Values of Cultural Heritage, research report, 5-30. Los Angeles, CA: The Getty Conservation Institute, 2002.

Moore-Gwyn, A., "Jubilee playing field" in Abercrombie, G. ed. Sustaining Memory. Sporting Heritage. $\quad$ Conservation bulletin. 68, 2, London: 2012.

Nicolai, B. (2002) "The Berlin Olympic Stadium, Who to deal with first 'Gesamtkunstwerk' of the Third Reich today?' in ICOMOS, Nationalkomitee der Bundesrepublik Deutschland (edt.), Sport Sites Culture, ICOMOS Journal of the German National Committee XXXVIII (2002): 37 - 38.

Rennie Short, J. A Review of "Olympic Cities: City Agendas, Planning, and the World's Games, 1896-2012", Annals of the Association of American Geographers, 99:1, (2009) : 227-228, doi: 10.1080/00045600802530281.

Schmidt, T. "Olympic Stadiums of the modern age - construction trends of the 20th century" in Sport Sites Culture in ICOMOS Journals of the German National Committee. XXXVII. ICOMOS Germany, (2002): 31 - 27.

"Eredità e sostenibilità di un'Olimpiade a dimensione umana". Spaziosport. Trimestrale di Architettura per lo Sport 13 (January/March 2010)

Stevenson, N. "Culture and the 2012 Games: creating a tourism legacy?" Journal of Tourism and Cultural Change, 10:2, (2012): 137-149. doi: $10.1080 / 14766825.2012 .682478$.

OCOG (Organizing Committee for the Olympic Games). The Games of the XVII Olympiad. Rome 1960. The Official Report of the Organizing Committee. V.2. Colombo Publisher, 1963.

Ortega y Gasset, José. Pasado y porvenir para el hombre actual. Madrid: Revista de Occidente, 1962. 
Pearson, J. "From the pavilion end: cricket's architectural héritage" in Abercrombie, G. ed. Sustaining Memory. Sporting Heritage. Conservation bulletin. 68. London: 2012.

Powell, K. "Wembley - Myth or Monument?" in Sport Sites Culture, ICOMOS Journals of the German National Committee. XXXVII. ICOMOS Germany, (2002): $66-68$.

Riegl Alois. Le culte moderne des monuments. Der moderne Denkmalkultus. Vienne Leipzig : Braumüller Verlag, 1903. Translated by Daniel Wieczorek. Reprint, Paris: Le Seuil, 1984.

UNAM. Technical file for the nomination of Campus central of the UNAM for the inscription in the UNESCO World Heritage, Mexico: UNAM, Conaculta, INAH, 2005.

UNESCO (United Nations, Educational, Scientific and Cultural Organization) "Convention du patrimoine mondial et développement durable", WHC12/36.COM/5C, 2012. Available at: www.whc.unesco.org.

Vecco, M. "A definition of cultural heritage: From the tangible to the intangible". Journal of Cultural Heritage 11, (2010): 321-324.

Velluet, P. in Abercrombie, G. (ed.) Sustaining Memory. Sporting Heritage. Conservation bulletin. 68, London: 2012.

Vittorini, R., DoCoMoMo Italiy. University Roma Tor Vergata, 2008. url: http://www.patrimoniosos.it/rsol.php?op=getcomunicato\&id=2820 .

Wansborough, M. and A. Mageean. "The role of Urban Design in Cultural regeneration". Journal of Urban Design 5, n. 2 (2000): 181 - 197.

Wood, Jason. "Sport, heritage and identity", in: Sporting Heritage, Gemma Abercrombie (eds). Conservation bulletin. 68, (2012): 3-4.

List of the National and Local Heritage official web sites consulted in 2012 - 2013

Stockholms Stadion:

http://www.raa.se/cms/en/cultural heritage 586/legislation_and resposibility/heritage conserv ation_act.html

Olympisch Stadion Amsterdam:

http://monumentenregister.cultureelerfgoed.nl/php/main.php

Olympiastadion Berlin:

http://www.stadtentwicklung.berlin.de/denkmal/landesdenkmalamt/

Melbourne complex:

http://www.environment.gov.au/heritage/places/national/mcg/index.html

Luzhniki Olympic Complex (Group of sculptures) :

http://www.kulturnoe-nasledie.ru/monuments.php?id=7710403000

http://www.kulturnoe-nasledie.ru/monuments.php?id $=7710404000$

http://www.kulturnoe-nasledie.ru/monuments.php?id=7710405000

Los Angeles Memorial Coliseum - Olympic stadium:

http://pdfhost.focus.nps.gov/docs/NHLS/Text/84003866.pdf

http://www.nps.gov/history/nhl

The Sydney Olympic Park Cauldron:

http://www.environment.nsw.gov.au/heritageapp/ViewHeritageItemDetails.aspx?ID=5061184 